Cell Research (2001); 11(4): 311-315

http://www.cell-research.com

\title{
Effect of heparin on apoptosis in human nasopharyngeal carci- noma CNE2 cells
}

\author{
LI Hong Liang ${ }^{1}$, Kai He YE ${ }^{1}$, Hai Wei ZHANG ${ }^{2}$, Ying Ru LUO ${ }^{1}$, XiAn Da REN $^{1 *}$, Ai Hua XIONG ${ }^{1}$, \\ RUI SITU ${ }^{2}$ \\ ${ }^{1}$ Department of Pharmacology, Pharmacy College, \\ ${ }^{2}$ Department of Pathology Medical College, Jinan University, Guangzhou 510632, China
}

\begin{abstract}
In order to study the mechanism of the effect of heparin on apoptosis in carcinoma cells, the nasopharyngeal carcinoma cell line CNE2 was used to identify the effect of heparin on apoptosis associated with the expression of c-myc, bax, bcl-2 proteins by use of Hoechst 33258 staining, terminal deoxynucleotidyl transferase-mediated dUTP nick-end labeling (TUNEL), agarose gel electrophoresis, and flow cytometry, as well as Western blot analysis. The results showed that heparin induced apoptosis of CNE2 cells including the morphologic changes such as reduction in the volume, and the nuclear chromatin condensation, as well as the "ladder pattern" revealed by agarose gel electrophoresis of DNA in a concentration-dependent manner. The number of TUNEL-positive cells was dramatically increased to $33.6 \pm 1.2 \%$ from $2.8 \pm 0.3 \%$ by treatment with heparin in different concentrations $(10 \sim 40 \mathrm{kU} / \mathrm{L})$. The apoptotic index was increased to $32.5 \%$ from $3.5 \%$ by detecting SubG1 peaks on flow cytometry. Western blot analysis showed that levels of bcl-2, bax and c-myc were significantly overexpressed by treatment with the increase of heparin concentrations. These results suggest that heparin induces apoptosis of CNE2 cells, which may be regulated by differential expression of apoptosis-related genes.
\end{abstract}

Key words: Heparin, agarose gel electrophoresis, flow cytometry, apoptosis,protein kinase C (PKC).

\section{INTRODUCTION}

Heparin is a polysulfated glycosaminoglycan with a high negative charge. Heparin is synthesized in various tissues, especially in the liver, lung, and gut. In addition to its anti-coagulant activity, heparin is known to have anti-hypertensive[1], anti-inflammatory [2], and anti-proliferative effects. Besides, heparin inhibits leukocyte rolling and its adhesion to endothelium, its aggregation, degranulation, and the generation of superoxide anion by activating neu-

\footnotetext{
* Correspondence to Prof. REN Xian-Da. Phn 86-20-8522-0261. E-mail: Tsam@jnu.edu.cn

Abbreviations: PKC, protein kinase C; TUNEL, terminal deoxynucleotidyl transferase-mediated dUTP nick-end labeling; NPC, nasopharyngeal carcinoma; PDGF, platelet-derived growth factor; IGF-I, insulin-like growth factor-I.

Received May-25-2001 Revised Oct-9-2001 Accepted Oct-312001
}

trophils[3-5]. Heparin and heparin sulfate proteoglycan inhibit mitogenesis and migration of cultured mesangial cells[6],[7]. It also exerts direct actions on the resident glomerular cells.

There are many actions for heparin to exert its effects on the malignant processes. Microthrombin with its fibrin formation, that is resulted from tumors and can in turn arrest tumor cells in capillaries[9], impede activity of natural killer cell[8]. Heparin prevents the formation of thrombin and neutralizes its activity. Heparin minimizes angiogenesis, that plays an important role in metastasis, via the inhibition of vascular endothelial growth factor and platelet activating factor. It decreases tumor cell adhesion to vascular endothelium as it inhibits actions of selectin and chemokine, and also decreases the replication and activity of some oncogenic viruses 
[10]. Heparin competitively inhibits tumor cell attachment to heparin sulfate proteoglycans, blocks the oncogenic action of ornithine decarboxylase, and enhances the antineoplastic effect of transforming growth factor $\beta$ [11]. Heparin inhibits activator-protein-1, that is the nuclear target of many oncogenic signal transduction pathways, and potently inhibits carcinogenic casein kinase II [12].

Although a number of biological properties have been postulated to explain the effects of heparin on the malignant process, it is still unknown whether and how heparin modulates survival of carcinoma cell. In this investigation, we address the potential effects of heparin for inducing the apoptosis of human nasopharyngeal carcinoma CNE2 cells.

\section{MATERIALS AND METHODS}

\section{Drugs and reagents}

Heparin, RPMI-1640 medium, RNase A, Agarose gel, Hoechst33258, Propidium iodide (PI), Proteinase K, were purchased from Sigma Chemical Co (St. Louis, MO, USA), Cell Death Detection Kit was obtained from Boehringer Mannheim. Antibax, anti- bcl-2, anti-c-myc, and anti-mouse beta-actin antibody, were purchased from Santa Cruz. CNE2 cell line was provided by Cancer Institute, Sun-Yet Sen University of Medical Sciences Guangzhou, China.

\section{Cell culture}

CNE2 cell line was cultured in RPMI-1640 medium, containing $10 \%$ new bovine serum, penicillin $\mathrm{G}(100 \mathrm{kU} / \mathrm{L})$, and kanamycin $(0.1 \mathrm{~g} / \mathrm{L})$ at $37^{\circ} \mathrm{C}$ in a $5 \% \mathrm{CO}_{2}$ air atmosphere.

\section{Hoechst 33258 Staining}

Cells were fixed with $4 \%$ formaldehyde in phosphate buffered saline (PBS) for $10 \mathrm{~min}$, stained by Hoechst33258 (10mg/L) for 1 $\mathrm{h}$, and then subjected to fluorescence microscopy. After treatment with heparin, the morphologic changes including reduction in the volume and nuclear chromatin condensation were observed.

\section{TUNEL}

TUNEL assay was performed using the apoptosis detection system. Cells were fixed with $4 \%$ paraformaldehyde in PBS overnight at $4^{\circ} \mathrm{C}$. The samples were washed with PBS and then permeabilized by $0.2 \%$ Triton X-100 in PBS for 15 min on ice. After washing, cells were equilibrated at room temperature for 15 to $30 \mathrm{~min}$ in equilibration buffer ( $200 \mu \mathrm{M}$ potassium cacodylate, 0 . $2 \mathrm{mM}$ dithiothreitol, $0.25 \mathrm{~g} / \mathrm{L}$ bovine serum albumin, and $2.5 \mathrm{mM}$ cobalt chloride in $25 \mathrm{mM}$ Tris-HCl, $\mathrm{pH}$ 6.6) and then incubated in the presence of $5 \mu \mathrm{M}$ fluorescein-12-dUTP, $10 \mu \mathrm{M}$ dATP, $100 \mu \mathrm{M}$ ethylenediaminetetraacetic acid (EDTA) and terminal deoxynucleotidyl transferase at $37^{\circ} \mathrm{C}$ for $1.5 \mathrm{~h}$ in the dark. The tailing reaction was terminated by $2 \times$ standard saline citrate (SSC).
The samples were then analyzed with fluorescence microscopy. At least 1000 cells were counted, and the percentages of TUNELpositive cells were determined.

\section{Ladder detection assay}

After induction of apoptosis, cells $\left(5 \times 10^{6} /\right.$ sample,both attached and detached cells) were lysed with $150 \mu$ l hypotonic lysis buffer (10mM EDTA, 0.5\% Triton X-100 in mM Tris-HCL, Ph7. 4) for $15 \mathrm{~min}$ on ice and were precipitated with $2.5 \%$ polyethylene glycol and $1 \mathrm{M} \mathrm{NaCl}$ for $15 \mathrm{~min}$ at $4^{\circ} \mathrm{C}$. After centrifugation at 16 , $000 \mathrm{~g}$ for $10 \mathrm{~min}$ at room temperature, the supernatant was incubated in the presence of proteinase $\mathrm{K}(0.3 \mathrm{~g} / \mathrm{L})$ at $37^{\circ} \mathrm{C}$ for one hour and precipitated with isopropanol at $-20^{\circ} \mathrm{C}$. After centrifugation, each pellet was dissolved in $10 \mu \mathrm{l}$ of Tris-EDTA ( $\mathrm{pH}$ 7.6) and electrophoresed on a $1.5 \%$ agarose gel containing ethidium bromide. Ladder formation of oligonucleosomal DNA was detected under ultraviolet light.

\section{Flow cytometry}

For DNA content analysis, heparin was added to CNE2 cells in mid-logarithmic phase $\left(1 \times 10^{9}\right.$ cells $\left./ \mathrm{L}\right)$. After $48 \mathrm{~h}, 1 \times 10^{6}$ cells were collected, pelleted, washed with phosphate-buffered saline (PBS), and resuspended in PBS containing $20 \mathrm{mg} / \mathrm{L} \mathrm{PI}$ and $1 \mathrm{~g} / \mathrm{L}$ ribonuclease A. $10^{6}$ fixed cells were examined per experimental condition by flow cytometry, and percentage of degraded DNA was determined by the number of cells displaying subdiploid (sub-G $\mathrm{G}_{1}$ ) DNA divided by the total number of cells examined.

\section{Western blot analysis}

The cells were lysed in lysis buffer (25 mM Hepes, $1.5 \%$ Triton $\mathrm{X}-100,1 \%$ sodium deoxycholate, $0.1 \% \mathrm{SDS}, 0.5 \mathrm{M} \mathrm{NaCl}, 5 \mathrm{mM}$ EDTA, $50 \mathrm{mM} \mathrm{NaF}, 0.1 \mathrm{mM}$ sodium vanadate, $1 \mathrm{mM}$ phenylmethylsulfonyl fluoride (PMSF), and $0.1 \mathrm{~g} / \mathrm{L}$ leupeptin) $(\mathrm{pH} 7.8)$ at $4^{\circ} \mathrm{C}$ with sonication. The lysates were centrifuged at 15 , $000 \mathrm{~g}$ for $15 \mathrm{~min}$ and the concentration of the protein in each lysate was determined with Coomassie brilliant blue G-250. Loading buffer (42 mM Tris-HCl, $10 \%$ glycerol, $2.3 \%$ SDS, $5 \% 2$ mercaptoethanol and $0.002 \%$ bromophenol blue) was then added to each lysate, which was subsequently boiled for $3 \mathrm{~min}$ and then electrophoresed on a SDS-polyacrylamidel gel. Proteins were transferred to nitrocellulose and incubated respectively with anti-bcl-2, -bax, and -c-myc antibody, and then with peroxidase-conjugated secondary antibodies. Detection was performed with enhanced chemiluminescence reagent.

\section{Statistical analysis}

Data are expressed as means \pm SD. Statistical analysis was performed using Student's test to compare data in different groups. A $\mathrm{P}$ value of $<0.05$ was used to indicate the statistically significant differences.

\section{RESULTS AND DISCUSSION}

\section{Effect of heparin on apoptosis of NPC cell line CNE2}

To examine the effect of heparin on the apoptosis, 
CNE2 cells were pretreated with heparin $(10 \mathrm{kU} / \mathrm{L}$ $40 \mathrm{kU} / \mathrm{L})$. The initiating effect of heparin on the CNE2 cell apoptosis was confirmed by observing Hoechst 33258-stained morphologic changes including reduction in the volume and nuclear chromatin condensation (not shown). Similarly, as shown in Fig 1, the number of TUNEL-positive cells was dramatically increased by the treatment with different concentrations of heparin, and the percentage of apoptosis was increased from $2.8 \pm 0.3 \%$ to $33.6 \pm$ $1.2 \%$. The pro-apoptosis effect of heparin was further confirmed by the ladder detection assay and flow cytometry. Agarose gel electrophoresis showed DNA ladder formation in exposed CNE2 cells. The DNA ladder was clearly embodied by the treatment with heparin (Fig 2). Low-concentration heparin (10 $\mathrm{kU} / \mathrm{L}$ ) was found to be sufficient to induce DNA fragmentation. It can be observed obviously that the profiles of DNA histograms were strikingly different from untreated CNE2 cells; the $\mathrm{subG}_{1}$ peak and apoptotic index were increased from $3.5 \%$ to $32.5 \%$ (Fig 3).

Heparin has been considered as an anti-mitotic agent for several cell types, especially for vascular smooth muscle cells and glomerular mesangial cells. However, little information is available concerning the effect of heparin on apoptotic processes. It is suggested by some reports that heparin may facilitate apoptosis in human peripheral blood neutrophils and in human lymphoblasts, mononuclear cells[13].

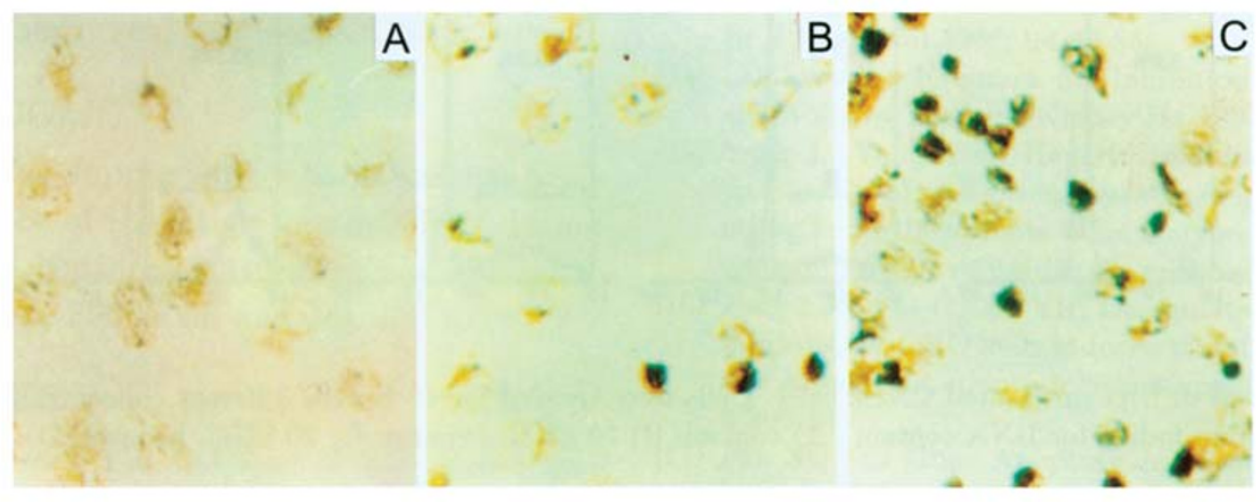

Fig 1. TUNEL assay demonstrating marked morphological changes in CNE2 cells after treatment with heparin. A)control; B) $20 \mathrm{kU} / \mathrm{L}$ heparin; C) $40 \mathrm{kU} / \mathrm{L}$ heparin. Original magnification is $200 \times$

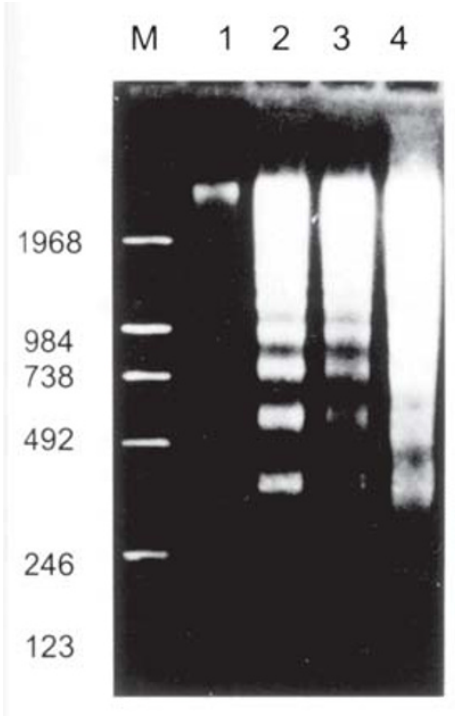

Fig 2. DNA ladder pattern formation in CNE2 cells after treatment with heparin. Cells were treated different concentrations of heparin for 48 $\mathrm{h}$ and the formation of oligonucleosomal fragments was determined by $1.5 \%$ agarose gel electrophoresis. M) DNA markers; 1) control; 2) $40 \mathrm{kU} / \mathrm{L}$ heparin; 3) 20 $\mathrm{kU} / \mathrm{L}$ heparin; 4) $10 \mathrm{kU} /$ $\mathrm{L}$ heparin
On the other hand, it is also suggested that heparin inhibits apoptosis in cultured mesangial cells and explanted glomeruli[14]. Nevertheless, the effect of heparin on apoptotic processes has not been clearly defined in carcinoma cells, although well studied in normal cells. In this investigation, we demonstrated a novel potential effect of heparin as an inducer of apoptosis in nasopharyngeal carcinoma (NPC) cell line, CNE2 cells, which showed that heparin induces the apoptosis of CNE2 cells in a dose-dependent manner.

Enhanced expression of c-myc and the ratios of bax/ bcl-2 in CNE2 cells exposed to heparin

Less is known about the molecular mechanisms underlying the pro-apoptotic action of heparin. Pre- 
vious researches have shown that heparin inhibits a PKC-dependent pathway for cell proliferation by suppressing the expression of c-fos and c-myc protooncogene, as well as IL-11 and GM-CSF mRNAs[15] in murine fibroblasts and vascular smooth muscle cells. Heparin, that was proved to be a potent inhibitor of $\mathrm{PKC}$, interacted with the catalytic domain of PKC. However, the present study, as shown in Fig 4, revealed that heparin increased the expression of bcl-2, bax, and c-myc in cultured human nasopharyngeal carcinoma (NPC) cell line CNE2.

It depends upon the interaction of other signals and related genes as whether or not c-myc in a particular cell type will promote cell proliferation and differentiation or induces apoptosis. The c-myc-me- diated apoptosis could be suppressed by cytokines such as platelet-derived growth factor (PDGF), insulin-like growth factor-I (IGF-I), and bcl-2.[16-19]. The c-myc promoter is characteristic of uniquely showing both RNA polymerase II (pol II) and RNA polymerase III (pol III) activities. Previous studies demonstrated that activating $\mathrm{PKC}$ resulted in upregulation of c-myc expression from its pol II promoter. PKC has recently been demonstrated to inhibit transcription from the pol III promoter of human c-myc gene[20]. Our present study showed that heparin, a potent inhibitor of PKC, increased the protein level of c-myc. It is possible that the overexpression of c-myc in heparin-treated CNE2 cells is related to the transcriptional inhibition of $c$-myc pol III promoter.
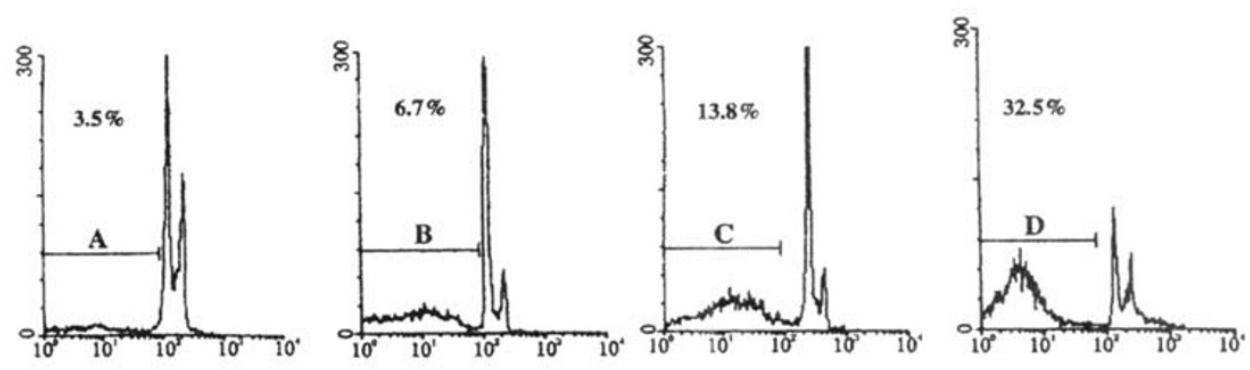

Fig 3. FACS anaiysıs or neparın-treatea Livez ceiss. Velıs were treatea tor $4 \varnothing \mathrm{n}$ witn airrerent concentratıons or heparin and stained with propidium iodide for DNA content. A) control; B) $10 \mathrm{kU} / \mathrm{L}$ heparin; C) $20 \mathrm{kU} / \mathrm{L}$ heparin; D) $40 \mathrm{kU} / \mathrm{L}$ heparin.

The $c-m y c$ proto-oncogene has two coupled opposing functions: proliferation and apoptosis, that suggests that other gene products may interact with c-myc so that the final output of cells could be determined. A candidate for such a modifying gene is probably bcl-2[21-23]. Activated bcl-2 gene could prevent apoptosis induced by c-myc. The bax, another bcl-2 family gene, was observed to increase when c-myc was overexpressed[24]. bcl-2 can form heterodimers with bax and lose its protective effect. When bax is present in excess, cells are susceptible to programmed cell death. Thus it seems that the relative ratios of bax and bcl-2, rather than the absolute values of either genes[25], determine the fate of a cell. Although we found that both bax and bcl-2 genes are expressed in cultured CNE2 cells, the changes were different in these two genes induced by heparin. The levels of bax protein in cultured CNE2 cells increased along with the increase of he-

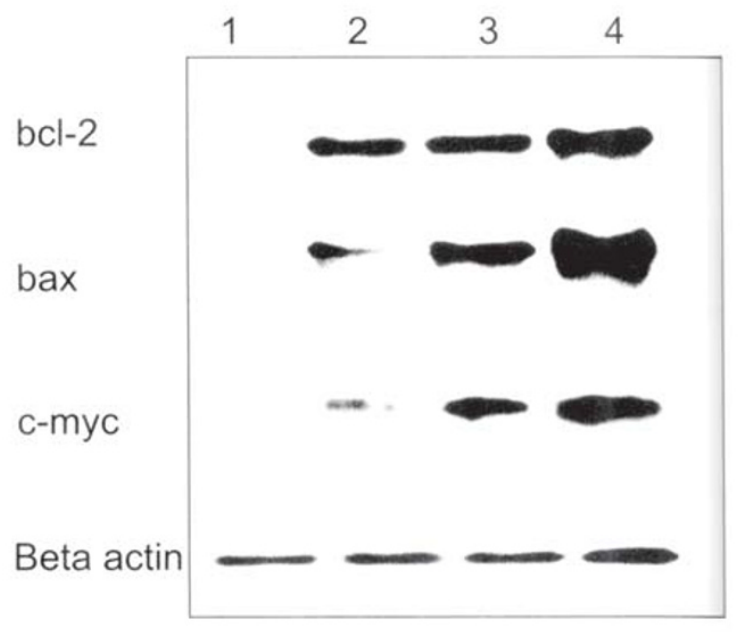

Fig 4. c-myc, bcl-2 and bax protein levels in CNE2 cells treated with heparin. Cell lysates were collected and processed at $48 \mathrm{~h}$. The whole cellular protein was separated in SDS-PAGE, Western blot was performed using antibodies against c-myc, bcl-2 and bax. Beta actin was used as a laneloading control. 1) control; 2) $10 \mathrm{kU} / \mathrm{L}$ heparin; 3) $20 \mathrm{kU} / \mathrm{L}$ heparin; 4) $40 \mathrm{kU} / \mathrm{L}$ heparin. 
parin concentrations. In contrast, the expression of bcl-2 showed no apparent changes after treatment with heparin in various concentrations. Therefore, according to the increased bax/bcl-2 ratio, the inhibitory effect of bcl-2 on c-myc-induced apoptosis might have been affected, and excessive expression of bax gene probably stimulated the apoptosis of CNE2 cells.

In conclusion, heparin induces apoptosis in CNE2 cells, which may be probably regulated by increased expression of c-myc and the rates of bax/ bcl-2. These findings suggest that heparin may function as an inducer of apoptosis in carcinoma cells. Further investigation will be required to determine the spectrum of pro-apoptotic potential effects in various carcinoma cells, as well as the molecular mechanisms underlying the pro-apoptotic action of heparin in human nasopharyngeal carcinoma CNE2 cells.

\section{ACKNOWLEDGMENT}

This work was supported by the Overseas Chinese Affairs Office of the State Council Foundation (No. 98-33) and National Natural Science Foundation of China (No. 39500056 and No. 39770300).

\section{REFERENCES}

[1] Mandal AK, Lyden TW, Saklayen MG. Heparin lowers blood pressure biological and clinical perspectives. Kidney Int 1995; 47:1017-24.

[2] Neison RM, Cecconi O, Roberts G, Aruffo A, Linhard RJ, Bcvilaqua MP. Heparin oligosaccharides bind L-and Pselection and inhibit acute inflammation. Blood 1993; 82: 3253-61.

[3] Ley K, Cerrito M, Arfors KE. Sulfated polysaccharides inhibit leukocyte rolling in rabbit mesentery venules. Am J Physiol 1991; 260:H1667-H1673.

[4] Bazzoni G, Beltran-Nunez A, Mascellani G. Effect of heparin dermatan sulfate and related oligo-derivatives on human polymorphonuclear leukocyte functions. J Lab Clin Med 1993; 121:268-75.

[5] Laghi-Pasini F, Pasqui AL, Ceccatelli L, Capecchi PL. Heparin inhibition of polymorphonuclear leukocyte action in vitro: A possible pharmacological approach to granulocyte- mediated vascular damage. Thromb Res 1984; 35:527-37.

[6] Groggel GC, Marinides GN, Hovingh P, Hammond E. Inhibition of rat mesangial cell growth by heparin sulfate. Am J Physiol 1990; 258:F259-F265.

[7] Krramura M, Mitaral T, Maruyama N, Nagasawa R. Mesangial cell behavior in a three-dimensional extracellular matrix. Kidney Int 1991; 40:653-61.
[8] Gunji Y, Gorelick E. Role of fibrin coagulation in protection of murine tumor cells from destruction by cytotoxic cells. Cancer Res 1988; 48:729-36.

[9] Markus G. The role of hemostasis and fibrinolysis in the metastatic spread of cancer. Thromb Hemost 1984; 10: 61-72.

[10] Beuth J, Ko HL, Pulverer G, Uhlenbrock G, Pichlmaier $H$. Importance of lectins for the prevention of bacterial i nfections and cancer metastasis. Glyconjugates 1995; 1 2:1-6.

[11] Vlodavssky I, Ishai-Michaels R, Morhren M, Bar-Shavit R, Catani R,Ekre H-P,et al. Modulation of meovascularizat ion and metastasis by species of heparin. Adv Exp Biol M ed 1992; 313:317-27.

[12] Busch SJ, Martin GA, Barnhart RL, Jackson RL. Transrepressor activity of nuclear glycosaminoglycans on fos and jun/AP-1 oncoprotein-mediated transcription. J Cell Biol 1992; 116: 31-42.

[13] Manaster J, Chezar J, Schurtz-Swirski R, Shapiro G, Tendler Y, Kristal B, Shasha SM, Sela S. Heparin induces apoptosis in human peripheral blood neutrophils. Br J Haematol 1996; 94:48-55.

[14] Lshikawa Y, Kitanura M. Inhibition of glomerular cell apoptosis by heparin. Kidney Int 1999; 56:954-63.

[15] Yang L. Yang Y-C. Heparin inhibits the expression of interleukin-11 and granulocyte-macrophage colony stimulating factor in primate bone marrow stromal fibroblasts through mRNA destabilization. Blood 1995; 86:2526-33.

[16] Fang CM, Shi C, Xu YH. Deregulated c-myc expression in quiescent $\mathrm{CHO}$ cells induces target gene transcription and subsequent apoptotic phenotype. Cell Research 1999; 9:305-14.

[17] Fan XQ, YJ Guo. Apoptosis in oncology. Cell Research 2000; 11:1-7.

[18] Harrington E, Fanidi A, Bennett M, Evan G. Modulation of myc-induced apoptosis by specific cytokine. EMBO J 1994; 13:3286-95.

[19] Fanidi A, Harrington E, Evan G. Cooperative interaction between c-myc and bcl-2 proti-oncogenes. Nature 1992; 359:554-6.

[20] Xu G, Gai Q, James CB. Protein kinase C inhibits transcription from the RNA poymerase III promoter of the human c-myc gene. Cancer Lett 1998; 123:199-205.

[21] Reed JC. Bcl-2 and the regulation of programmed cell death. J Cell Biol 1994; 124:1-6.

[22] Chang YC, Xu YH. Expression of Bcl-2 inhibited Fasmediated apoptosis in human hepatocellular carcinoma BEL-7404 cells. Cell Research 2000; 10:237-42.

[23] Yin XM. Signal transduction mediated by Bid, a pro-death Bcl-2 family. Cell Research 2000; 10:161-7.

[24] Sakamuro D, Eviner V, Elliott KJ, Show L, White E. Cmyc induces apoptosis in epithelial cell by both p53dependent and p53-independent mechanisms. Oncogene 1995; 11:2411-8.

[25] Oltvai ZN, Milliman CL, Korsmeyer SJ. Bcl-2 heterodimerizes in vivo with a conserved homolog, bax, that accelerates programmed cell death. Cell 1993; 74: 609-19. 